\section{STUDY OF ACTUAL ENERGY USE SITUATION IN GENERAL FAMILY AND THE INTRODUCTION OF RENEWABLE ENERGY IN MYANMAR}

\section{May HSU SHIN_— $* 1$ \\ Kazuhiro IWAI

$* 3$

\section{Naoki TAKAGI}

$* 2$

Keywords:

Renewable energy, Electrical energy, Photovoltaic energy, Wind energy, Energy conservation

キーワード :

再生可能エネルギー, 電力エネルギー, 太陽エネルギー, 風カエネルギー, 省エネルギー

\section{ミャンマーの一般家庭における エネルギー利用の実態と再生可 能エネルギー導入に関する研究}

メイスーシンー* $* 1$
岩井一博—3

The main focus of the study is to find out the actual energy use in electrified area and consider the way to improve it. First, actual energy use is investigated by questionnaire survey and find out the problem. Next, the potential of renewable energy such as photovoltaic energy and wind energy are investigated by actual survey. At the end a consideration for resolving the problem was made by energy conservation and introducing renewable energy. The study resulted to figure out a way to improve the energy using condition not only in the targeted area, but also in similar areas.

\section{Introduction}

In Myanmar, energy consumption is increasing due to the recent development and energy shortage is a serious issue to resolve. Even in Yangon, the biggest city and the center of economy in Myanmar, blackout occurs repeatedly. According to Department of Hydropower Planning 2013 , only $29 \%$ of 8.9 million houses are electrified, and most of them are concentrated in big cities.

According to "Accelerating Energy for All in Myanmar (UNDP)", $2012.5^{1)}$, energy consumptions in household occupies $76 \%$ of the total energy consumptions, the second is $10 \%$ occupied by distribution and followed by industry which occupied $8 \%$. Hydropower occupied $61 \%$ of all electrical power and natural gas is $34 \%$ as second largest for generation. There is no nuclear power plant in Myanmar. Hydropower is already taking the biggest part in power supply but we still have more renewable energy resources to use, such as photovoltaic and wind energy. Charcoal and firewood are common in cooking and heating. Because of Lumbering and urban developments, the area of forest is $10 \%$ decreasing in 2010 comparing to 2000 . As a result, the areas where firewood and charcoal can be taken are decreasing. Recently, gas becomes popular for cooking in some part of big city, too.

In Myanmar, the electricity use is varied by the differences of life style. The main purpose is lighting, followed by televisions and radio. The next step is to cook and using fans. Then, it is followed by using household electric appliances such as refrigerators, washing machines and microwave oven, etc. Water heater is not popular among general families.
Liquefied petroleum gas (LPG) ${ }^{(1)}$ and charcoal is used for cooking in some houses. From the past studies, it is already noticed that Myanmar has highly potential in solar energy ${ }^{2)}$ and wind energy in some parts. In solving energy shortage problem, the first step is energy conservation in electrified area and share the energy to non- electrified area. The second step is to introduce renewable energy such as photovoltaic energy and wind energy to help electrification.

\section{Objectives}

There are three main points in this study. First is to find out how people are using energy in electrified areas, such as what types of energy are using, and how much energy is using in each month. Two areas are chosen and they are Yangon, the urban city and Pyin Oo Lwin, the rural city. Next is to study the potential of renewable energy such as photovoltaic energy and wind energy for the targeted areas. And the third one is to make a plan to help resolving energy shortage issue.

\section{Survey and research methods}

At first, in this study, we chose two characteristically different areas Yangon and Pyin Oo Lwin. This is to find out the difference of energy use between urban area and rural area. Yangon is located in the southern part of Myanmar, close to the sea and the altitude is 13 meters. This is the biggest city and the center of economy, trade and education. Pyin Oo Lwin is situated 760 kilometers distance north of Yangon and the altitude is 1070 meters.

\footnotetext{
Graduate Student (M. Course), Dept. of Architecture, Graduate school of Science and Engineering, Shinshu Univ.

Prof., Dept. of Architecture, School of Engineering, Shinshu Univ., Dr. Eng.

"3 Research Assoc., Dept. of Architecture, School of Engineering, Shinshu Univ., Dr. Eng.
} 


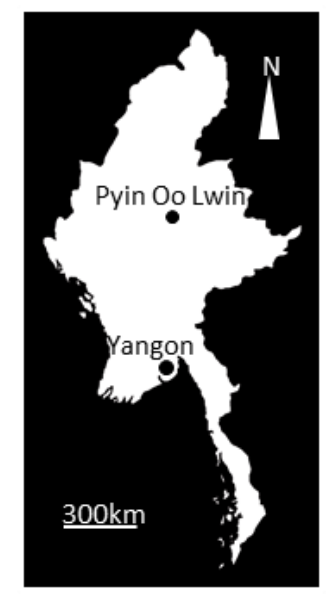

Fig. 1 Location of the targeted cities

Table 1 The characteristics of targeted areas

\begin{tabular}{|c|c|c|}
\hline & Yangon & Pyin Oo Lwin \\
\hline Area $\left(\mathrm{km}^{2}\right)$ & 576 & 1,975 \\
\hline Population & $4,000,000$ & 150,000 \\
\hline No. of Households & $1,590,000$ & 30,000 \\
\hline Latitude & $16^{\circ} 46^{\prime} \mathrm{N}$ & $22^{\circ} 2^{\prime} \mathrm{N}$ \\
\hline Longitude & $96^{\circ} \quad 9^{\prime} \quad \mathrm{E}$ & $96^{\circ} 27^{\prime} \mathrm{E}$ \\
\hline Altitude $(\mathrm{m})$ & 13 & 1,070 \\
\hline Average $\mathrm{High}\left({ }^{\circ} \mathrm{C}\right)$ & 33 & 28 \\
\hline Average Low $\left({ }^{\circ} \mathrm{C}\right)$ & 24 & 17 \\
\hline Humidity (\%) & 60 & $\overline{68}$ \\
\hline
\end{tabular}

We made a questionnaire survey to find out the actual energy use in these targeted areas. The survey was performed in September, 2014, for 125 houses in Yangon and 50 houses in Pyin Oo Lwin. We went to the workplace and different types of houses for the survey. In this survey there are three main parts, ${ }^{1)}$ about family, ${ }^{2}$ what kinds of energy is using for what purposes, and ${ }^{3)}$ how much energy is using in every month.

Next, we made a measurement survey to find out the global solar radiation, wind speed and wind and wind direction. From the data, we investigated how much energy can be taken from photovoltaic and wind energy. Then consider a plan to use the renewable energy efficiently.

\section{Questionnaire Survey}

\section{4-1 About household}

According to this questionnaire, we found out $58 \%$ of houses are flat and $42 \%$ is detached house and these are common in Yangon. As Yangon is the biggest city in Myanmar, it becomes populated than recent years and the housing demand is continuing. The metropolitan area is mainly occupied by mid-to-high-rise buildings. The suburb area is mainly covered by detached houses. In Pyin Oo Lwin, detached house are common and it occupies $77 \%$ of houses (Fig. 2).From Fig. 3, two households family occupies $66 \%$ of families in Yangon and it also occupies almost half of the types of families in Pyin Oo Lwin.

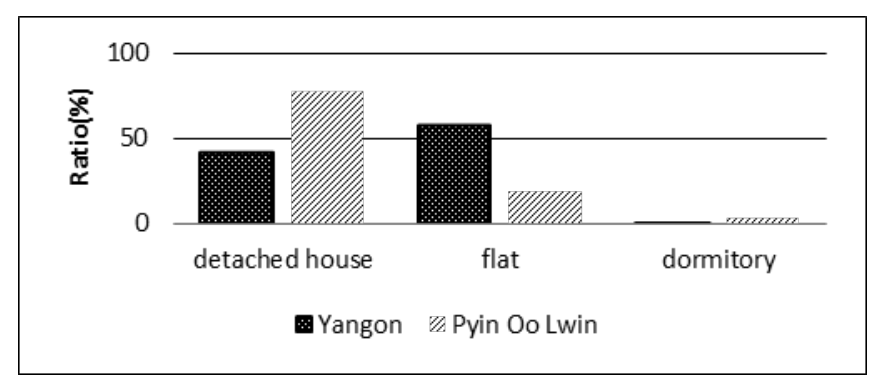

Fig. 2 Type of houses

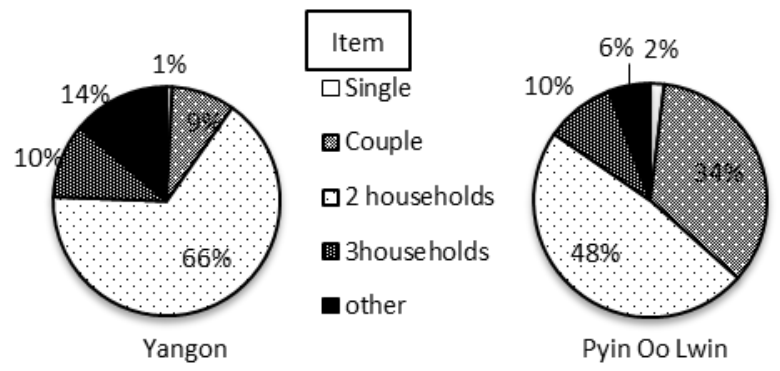

Fig. 3 Types of households in Yangon and Pyin 0o Lwin

\section{4-2. Actual energy use}

In this session we investigated about what kind of energy is using for which purposes, especially for huge energy consumption uses such as cooking, air-conditioning and heating. From Fig. 4, in cooking, more than $90 \%$ of houses are using electricity in both cities. Most of the houses said that electricity is the main energy to cook and the other energy such as charcoal and gas are used as a spare for the time of blackout. Only a few houses use firewood for cooking.

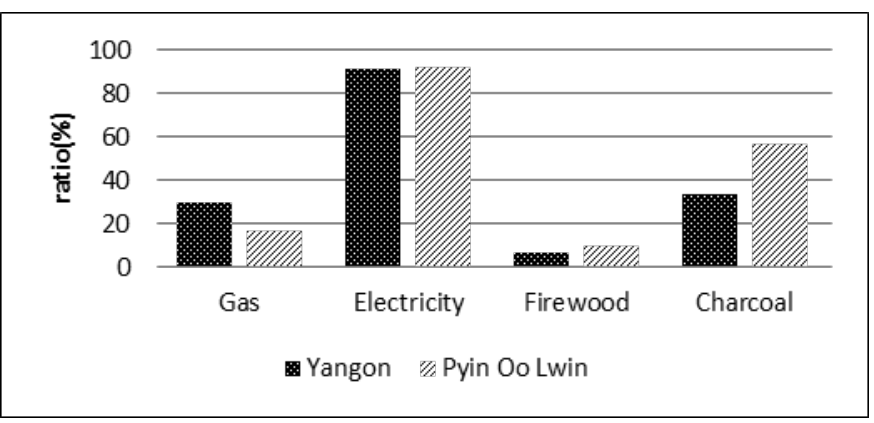

Fig. 4 Frequency of ratio of energy use in cooking

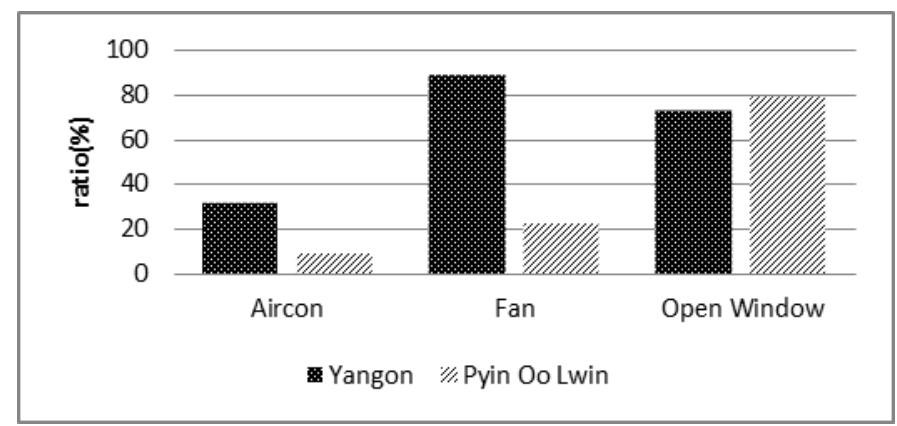

Fig. 5 Frequency of ratio of cooling method 
Even Myanmar has a hot weather, according to Fig. 5, just $30 \%$ of the households use air conditioner in Yangon and less than $10 \%$ of people uses in Pyin Oo Lwin. In Yangon 90\% of houses uses fan which is the most common cooling method in Yangon. From Fig. 5, we can see that cooling doesn't occupy the main part of energy consumption. For heating, in Pyin Oo Lwin, a few people use firewood, and for water heater, just a few people use water heater. As a result the energy consumption for heating and water heating can be ignored.

\section{4-3 The amount of energy use}

We investigated that how much gas, electricity and charcoal are used in each month by filling the cost in the questionnaire. The result is as follows in Fig. 6. The electricity is mainly used both in Yangon and Pyin Oo Lwin and the charcoal is used more in Pyin Oo Lwin than in Yangon. The reason is blackout occur more rapidly in Pyin Oo Lwin than in Yangon.

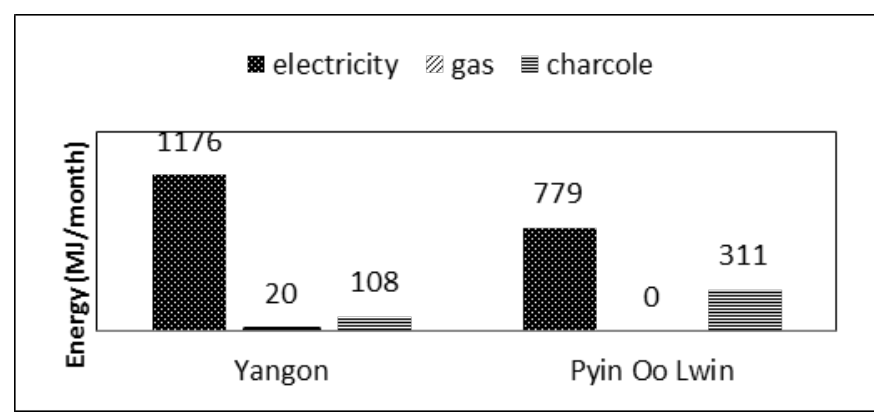

Fig. 6 The amount of energy use in a month per a house

We couldn't find any big difference of energy use by months. To consider energy conservation, we focus on the use of electricity. In Yangon, $327 \mathrm{kWh} / \mathrm{month}$ of electricity is used while $216 \mathrm{kWh} / \mathrm{month}$ is used in Pyin Oo Lwin. According to "the Federation of Electric power Companies of Japan", $283.6 \mathrm{kWh} /$ month is used in average household of Japan in 2008. The following Table.2 shows the standard deviation, standard error, maximum and minimum values of the electricity used in Yangon and Pyin Oo Lwin.

Table 2 The other statistics data of electricity use

\begin{tabular}{|l|r|r|}
\hline & YGN & POL \\
\hline SE & 26.77 & 16.87 \\
\hline SD & 279.51 & 119.26 \\
\hline $\operatorname{mim}$ & 100 & 65 \\
\hline $\max$ & 1800 & 600 \\
\hline
\end{tabular}

Even though Myanmar is using less electrical appliance in household than Japan and have electricity blackout, the households in Yangon is using more electricity than Japan.

There are two reasons why Myanmar is using so much electric energy. One is the spread of gas cooking devices is slow, although Myanmar has rich of natural gas. Nowadays, some cars and buses are using natural gas instead of gasoline because it is cheaper. But for the kitchen use, it is still expensive that the majority could not effort to use gas in kitchen. The second is Myanmar still use electric heat cooking devices. Comparing to other electric cooking devices such as electromagnetic cooking device, electric heat cooking device uses more energy. Recent electromagnetic cooking devices have $85 \%$ of thermal efficiency while electric heat cooking device has $55 \%$ of thermal efficiency and need more time to cook. Energy saving is expected by using electromagnetic cooking devices.

\section{Measurement survey}

The overview of measurement is as follow in table 3. The devices were set on the roof top of Yangon Technological University main building in Yangon and for Pyin Oo Lwin these were set on the roof top of the two houses. The data is collected once in three or four months.

Table 3 Overview of measurement survey

\begin{tabular}{|l|l|l|l|}
\hline Item & Period & Interval & Devices \\
\hline $\begin{array}{l}\text { Temperature and } \\
\text { Humidity }\end{array}$ & $\begin{array}{c}21 / 9 / 2013 \sim \\
1 / 9 / 2014\end{array}$ & every 20mins & $\begin{array}{c}\text { Thermometer, } \\
\text { Hydrometer }\end{array}$ \\
\hline Global Solar Radiation & $\begin{array}{c}21 / 9 / 2013 \sim \\
1 / 9 / 2014\end{array}$ & every 10mins & Pyrheliometer \\
\hline Wind Speed and Wind & $\begin{array}{c}21 / 9 / 2013 \sim \\
1 / 9 / 2014\end{array}$ & every 20mins & $\begin{array}{c}3 \text { cup } \\
\text { Direction }\end{array}$ \\
\hline
\end{tabular}

\section{5-1 Temperature and Humidity}

Temperature and humidity are measured by thermometer and hydrometer set up outside of the building under the shade. In Myanmar, there are three seasons, hot season, rainy season, and cold season. The hot season lasts from the end of February to the beginning of May. The wet season lasts from the middle of May to the end of October. The cold season lasts from November to February. The hot season in Yangon has less than $20 \%$ of humidity which makes the weather feel better.

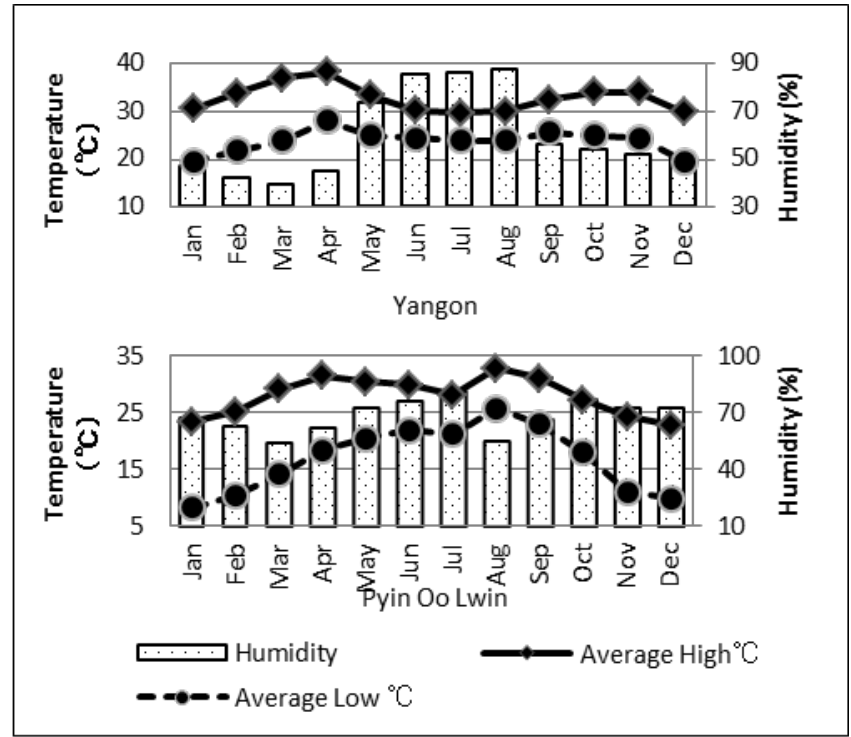

Fig. 7 Temperature and Humidity of Yangon and Pyin 0o Lwin 


\section{5-2 Photovoltaic Energy}

The measurement survey was held for almost a year in both Yangon and Pyin Oo Lwin. We measured global solar radiation from the September of 2013 to September of 2014. The Pyrheliometer was set up horizontally, and recorded the instant data for every 10 minutes. From global solar radiation, insolation on tilted surfaces is estimated by separating direct and diffuse insolation, with using Erbs (1982) model ${ }^{33}$. As a result, we found out that 30 degree slope from horizontal is the most suitable angle to set the photovoltaic panel in both cities.

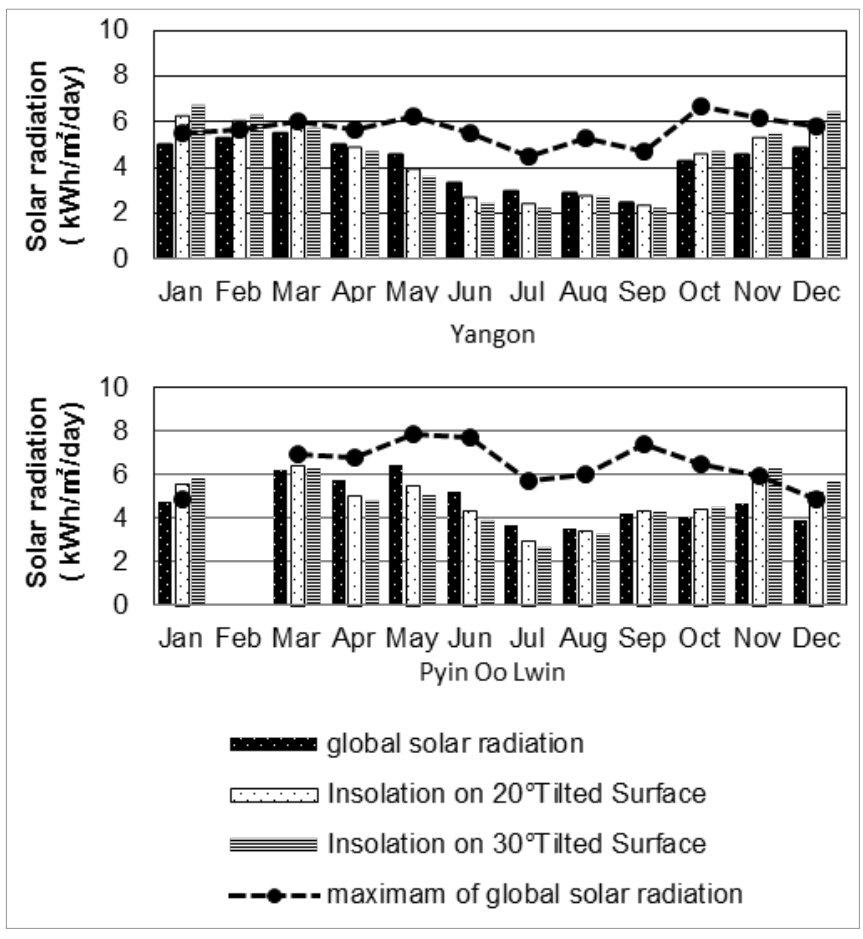

Fig. 8 Average solar radiation in Yangon and Pyin 0o Lwin

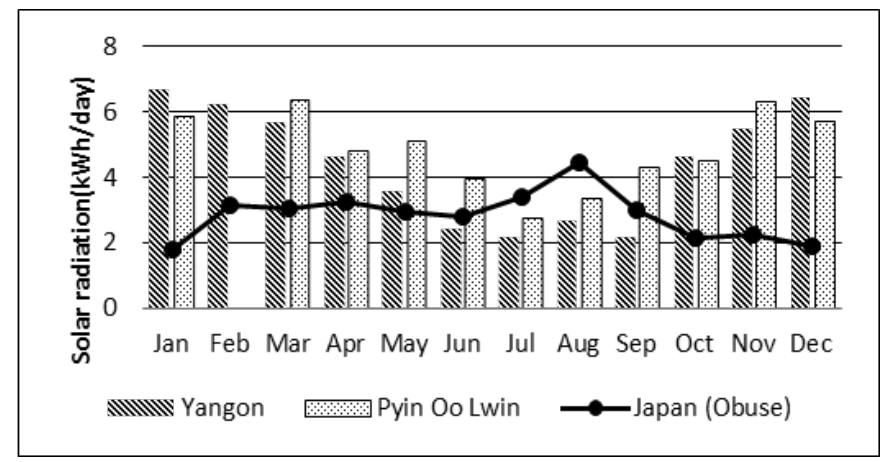

Fig. 9 The comparison of insolation on $30^{\circ}$ tilted surface in Yangon, Pyin 0o Lwin and Obuse City

Figure 8 shows the monthly average daily solar radiation. From the middle of May to October, the solar radiation decreases because it is the rainy season. But for other seasons, a huge potential of photovoltaic energy can be expected. Fig. 9 is the comparison of solar radiations between Yangon, Pyin Oo Lwin and a point in Japan, Obuse city ${ }^{4)}$, a city located in the northern part of Nagano Prefecture which has a big potential in photovoltaic energy that has been known from previous studies of Nakata Megumi (2011). We can say that photovoltaic power generation is suitable for both Yangon and Pyin Oo Lwin.

\section{5-3 Wind Energy Survey}

Wind speed and wind direction was measured from September of 2013 to September of 2014. Measurement interval is 20 mins. The result is as follow in Fig. 10. Average wind speed is under $1.5 \mathrm{~m} / \mathrm{s}$ in every season. Common home wind power generator starts generate electricity at wind speed of $3 \mathrm{~m} / \mathrm{s}$. According to previous studies of Nakata Megumi (2011) ${ }^{5}$, even with the low wind speed cut-in generator, average wind speed less than $1.5 \mathrm{~m} / \mathrm{s}$ is not suitable for wind power generation. So, in both Yangon and Pyin Oo Lwin, wind power generation could not be expected.

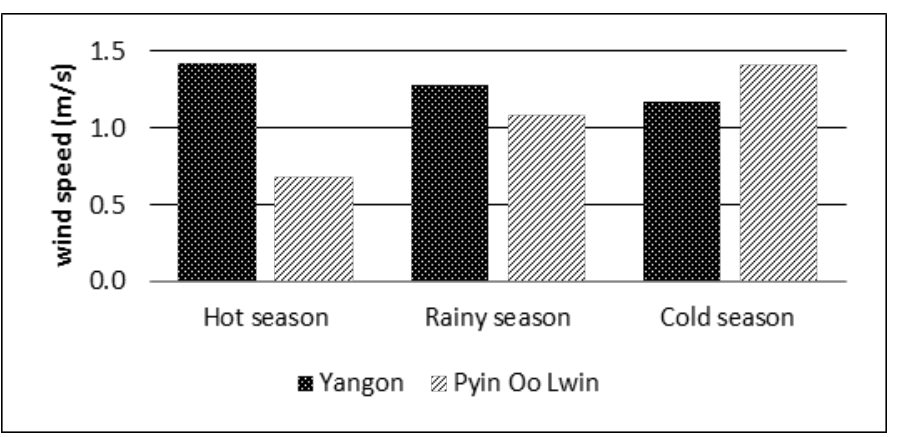

Fig. 10 Average wind speed per day by season

6. Introducing renewable energy

From the measurement survey of renewable energy, it is cleared that both cities has a huge potential of photovoltaic power generation. From the data , photovoltaic power generation is considered using the equation (1). The scales refer to a general house in Japan with photovoltaic generation system.

Capacity of the system: $3.28 \mathrm{~kW} \quad$ Sharp: $160 \mathrm{~W}$,

No. : 24pieces,

Efficiency of generation: $11 \%$,

Tilt sunlight: tilt sunlight of $30^{\circ}$ angle from horizontal for each month Solar power $=$ tilt sunlight $\times$ collecting area $\times$ generation Generation efficiency
( $\mathrm{kWh} /$ day)
$\left(\mathrm{kwh} / \mathrm{m}^{2} /\right.$ day)
$\left(m^{2}\right)$

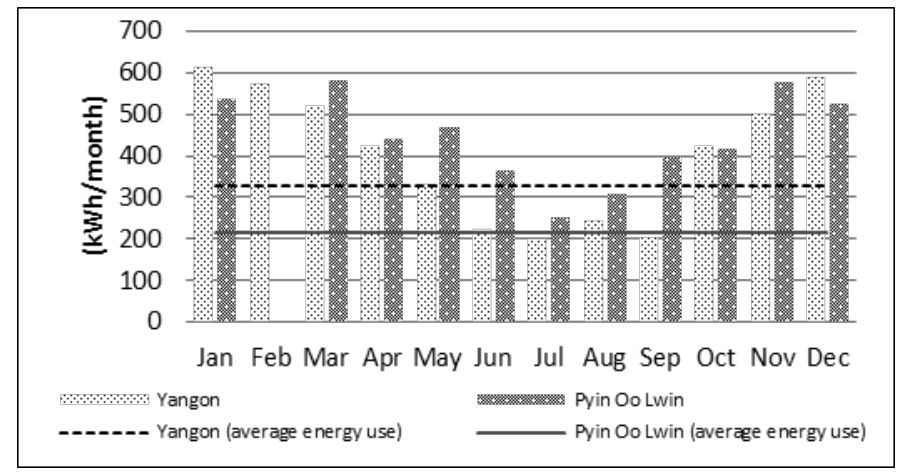

Fig. 11 The potential of photovoltaic generation in Myanmar 
The result is shown in Fig. 11. In both cities, with using of $3.28 \mathrm{~kW}$ generation system, the power generated is more than the average energy use. For Yangon, from October to May, the 8 months can generate more than the demand. Even though from June to September is the rainy season, it generate at least $200 \mathrm{kWh} /$ month which is around two third of total demand.

For Pyin Oo Lwin, the solar radiation condition is better than Yangon and the energy demand is less than Yangon, every month can generate more than the demand. From September to May the 9 months can generate more than twice of the demand.

Although it has many potential, the photovoltaic energy spread situation in Myanmar is still getting behind. It is mainly use for lighting in non-electrified areas and street light for expressway. Because of the initial cost, it is very expensive to use in general family. Myanmar does not have feed-in tariff system ${ }^{(2)}$ like Japan, United States and the other countries to initiate and accelerate the use and investment of renewable energy. Therefore, the person who uses the generator has to pay every single cost of the system.

On the other hand, only independent type of photovoltaic generator can be used, which need battery to save energy for the nighttime. If we use this energy in day time opening buildings such as, schools, universities, offices and so on, the big capacity of battery would not be needed, and the energy will be used effectively. Next issue is to figure out how much energy is used in schools, offices, supermarkets and so on.

\section{Conclusions}

Now, Myanmar is on the way to developing future. There is two way, one is follow the developed countries' history, and the other is to write the own history considering the environment and build a sustainable society ${ }^{(3)}$. For the second path, knowing about environment is necessary. For example, Myanmar has electricity power shortage, but the waste of energy is unknown. There is room to be improved. In this study, small hints to rise up the lifestyle with considering environment were found out. These are summarized as follow.

1) $90 \%$ of the households in both cities is using electricity for cooking but charcoal and gas are also used when electricity blackout. In Pyin Oo Lwin the frequency of using charcoal is more than Yangon. On the other hand, the frequency of using gas in Yangon is more than Pyin Oo Lwin. Cooking occupy a big part of electricity use.

2) In Pyin Oo Lwin cooling system does not need to be used, but in Yangon almost $90 \%$ of households uses fan and $30 \%$ uses air conditioner. The electricity energy occupied by cooling system can't be seen in Pyin Oo Lwin but Yangon has.

3) By changing electric heat cooking devices to electromagnetic cooking devices, the electricity can be saved in a large amount.

4) Both cities depend mostly on electricity but Yangon uses more electricity in average households.

5) Both Yangon and Pyin Oo Lwin have a big potential for photovoltaic energy, especially in Pyin Oo Lwin. If we introduce this generation system to electrified area, it is better to use in public places than houses.

The next issue is to find out the actual energy use in public buildings. For energy conservation, the first step is to know the actual condition, and then compare to the other that already have standard. Next is to find out where the waste is. And finally, make the own standard. In Myanmar, the idea of saving energy is not serious as Japan.

For the electrified places, people do not even grasp their energy usage which leads to wasting energy. On the other hand, there are houses still using candle and kerosene lights at night. So, making the standard for energy using is very important to write the energy plan for development.

\section{Notes}

(1) LPG

Liquefied petroleum gas refers to flammable gases, propane or butane which is used in heating devices, cooking appliance and vehicles.

\section{(2) Feed-in tariff system}

This is a policy mechanism to accelerate investment in renewable energy technologies. This is held in United States, Japan, India and Germany and so on. It includes guaranteed grid access, long-term contract, cost-based purchase prices.

\section{Acknowledgement}

This study was started by the cooperation of Yangon Technological University. We would like to express our appreciation to Yangon Technological University. We also appreciate Mr. Myint Kyu for helping us with everything in Pyin Oo Lwin, and the people who helped us with questionnaires, actual study and the cooperation of statistical data from Ministry of construction, Myanmar.

\section{References}

1) Accelerating Energy For All in Myanmar (UNDP), Pg.8, 2012.5

2) Thet Thet Han Yee: Solar Energy Potential and Applications in Myanmar, World Academy of Science, Engineering and Technology, Vol: 2 2008. 06. 22

3) Erbs, D.G., S.A.Klein, J.A.Duffie : Estimation of the Diffuse Radiation Fraction for Hourly, Daily and Monthly Average Global Radiation, Solar Energy, Vol.28, No.4, pp.293-302,1982

4） May Hsu Shin、他 1 名：小布施町役場における災害時非常用電源シス テムに関する研究：太陽光発電を利用した提案、日本建築学会北陸支 部研究報告集 $(56), 235-238,2013.5$

5）仲田めぐみ、他 1 名：長野県北信地方の新エネルギーに関する研究、日 本建築学会学術講演梗概集 2011.8 (関東)

6）古市隼斗、多 2 名: 秦野市における再生可能エネルギー導入可能性に関 する研究、日本建築学会学術講演梗概集、2011.8（関東）

[2015 年 1 月 30 日原稿受理 2015 年 5 月 2 日採用決定］ 